\title{
Chemical properties of the graptolite periderm from the Holy Cross Mountains (Central Poland)
}

\author{
Rafat Morga
}

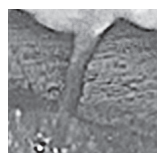

\begin{abstract}
Graptolite periderm in the Silurian shales from the Holy Cross Mountains of the Central Poland was examined by means of reflectance measurements and micro-FTIR spectroscopy. Mean graptolite reflectance $\left(\mathrm{R}_{\mathrm{r}}\right)$ reaches $0.70-0.77 \%$, and the vitrinite reflectance equivalent (VRE) is $0.67-0.72 \%$. Graptolite periderm is composed predominantly of aromatic groups and rings with lesser amount of aliphatic and carbonyl/carboxyl groups. Chemical composition does not vary significantly between the samples from the two considered localities (the Pragowiec ravine and Bardo Stawy), which corresponds to the narrow range of graptolite reflectance. However, the samples from the Pragowiec ravine are characterized by higher hydrocarbon potential. It is found that many similarities occur in the chemical structure of the graptolite periderm and vitrinite within the reflectance range of $\mathrm{R}_{\mathrm{r}} \approx 0.7-1.5 \%$. With increasing reflectance the length of the aliphatic chains (as inferred from the $\mathrm{CH}_{2} / \mathrm{CH}_{3}$ ratio) in the graptolite periderm decreases, and the relative content of the aromatic groups [as indicated by the $\mathrm{CH}_{\mathrm{ar}} /\left(\mathrm{CH}_{2}+\mathrm{CH}_{3}\right)$ ratio] begins to increase at $\mathrm{R}_{\mathrm{r}} \approx 1.6 \%$. This is accompanied by growth of the coherent domains and improvement in the structural order. $\bullet$ Key words: graptolites, chemical structure, infrared spectroscopy, Holy Cross Mountains.
\end{abstract}

Morga, R. 2020. Chemical properties of the graptolite periderm from the Holy Cross Mountains (Central Poland). Bulletin of Geosciences 95(2), 205-213 (10 figures, 1 table). Czech Geological Survey, Prague. ISSN 1214-1119. Manuscript received September 6, 2019; accepted in revised form April 17, 2020; published online May 16, 2020; issued May 30, 2020.

Rafat Morga, Silesian University of Technology, Akademicka 2, 44-100 Gliwice, Poland; rafal.morga@polsl.pl

Graptolite reflectance $\left(R_{r}\right)$ is one of the most important indices of thermal maturity of pre-Upper Silurian rocks, in which vitrinite does not appear (e.g. Goodarzi 1984, 1985; Goodarzi \& Norford 1985, 1987, 1989; Link et al. 1990; Cole 1994; Petersen et al. 2013; Luo et al. 2020). It is commonly employed in the recognition of the unconventional hydrocarbon deposits, which frequently occur in the Cambrian-Silurian organic-rich shales (e.g. Więcław et al. 2010, Schovsbo et al. 2011, Jarvie 2012, Petersen et al. 2013). However, the chemical structure of the graptolite periderm (or fusellum sensu Maletz et al. 2014) is still not fully resolved. Periderm of living graptolites was composed of collagen-like fibrils but their corresponding fossil counterparts lack protein and they underwent the coalification process similar to plant remains (Towe \& Urbanek 1972, Link et al. 1990). Deep insight into graptolite paleobiology was given by Maletz et al. (2017). Research on the chemistry of the fossilized graptolite periderm (Bustin et al. 1989; Suchý et al. 2002, 2004; Caricchi et al. 2016; Morga \& Kamińska 2018; Luo et al. 2020) were mostly performed on graptolite specimens, reflectance $\left(R_{r}\right)$ of which exceeded values of $0.8-1 \%$, and still little is known about chemistry of low reflectance graptolites. The purpose of this investigation is to determine, for the first time, chemical properties of the graptolite periderms from the Holy Cross Mountains $\left(\mathrm{R}_{\mathrm{r}}<0.8 \%\right)$, and compare them to those known from the previous studies. The research is a continuation of the microstructural examination performed on the same samples (Morga 2019).

\section{Geological setting}

Four samples were collected from the outcrops of the Silurian rocks in Bardo Stawy and the Pragowiec ravine in the Holy Cross Mountains (HCM), Central Poland. Both localities are situated within the Bardo Syncline in its southern and northern limb, respectively, ca $35 \mathrm{~km}$ SEE of the town of Kielce (Fig. 1). Due to outstanding geological and paleontological importance, they are very well-described (Tomczykowa 1958, Modliński \& Szymański 2001, Masiak et al. 2003, Trela \& Salwa 2007, Smolarek et al. 2014, Mustafa et al. 2015, Schito et al. 2017). The Silurian rocks exhibited in Bardo Stawy belong to Llandovery series, while those in the Pragowiec ravine to Wenlock-Lower Ludlow. Two samples were taken in each locality, in the uppermost and lowermost parts of the Silurian strata, from a fresh rock to minimize the effects of weathering. Silurian rocks in Bardo Stawy 


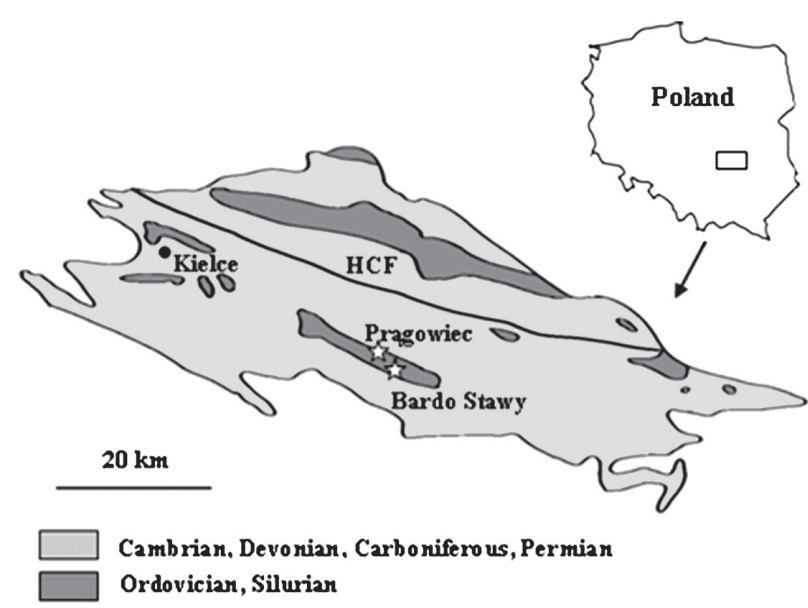

Figure 1. Geological sketch of the Holy Cross Mountains with the location of the sampling points (modified from Kremer 2001).

are mainly graptolitic dark grey shales with intercalations of radiolarian shales, while those at the Prągowiec ravine are mainly calcareous clay shales and siltstones, passing into graptolite-rich dark grey clay shales. They contain macroscopically visible graptolite remains. Geological setting and graptolite assemblages of Bardo Stawy were given in detail by Modliński \& Szymański (2001), Masiak et al. (2003), and Trela \& Salwa (2007), whereas broad description of the Pragowiec ravine geology and palaeontology one can find in Tomczykowa (1958) as well as Modliński \& Szymański (2001).

\section{Methods}

Morphological and optical features of graptolites under reflected light were described in detail by Teichmüller (1978), Goodarzi (1984, 1985), Goodarzi \& Norford (1985, 1987), and Link et al. (1990), among others.

Graptolite reflectance was measured on polished sections parallel to the bedding by the use of a Zeiss Axioskop microscope, in immersion oil $\left(\mathrm{n}_{\mathrm{o}}=1.518\right.$ at $23{ }^{\circ} \mathrm{C}$ ) in 32 to 54 randomly chosen spots per sample. Only the well-preserved, homogenous areas were chosen. All other aspects of the measuring procedure followed the ISO 7404-5 (2009) standard. Based on that mean values $\left(\mathrm{R}_{\mathrm{r}}\right)$ and standard deviations were calculated. All reflectance measurements were performed on non-granular graptolites (sensu Goodarzi 1984) to avoid possible scattering of the light beam on a granular tissue (Fig. 2).

Micro-FTIR analysis was carried out in reflectance mode, with the use of a Bio-Rad FTS-6000 spectrometer, equipped in the Bio-Rad UMA 500 microscope. Number of measurement points per sample varied between 10 and 12. Spectra were obtained within the range of $6000-750 \mathrm{~cm}^{-1}$, at a resolution of $4 \mathrm{~cm}^{-1}$. Interferograms were collected by co-adding of 512 scans, using a gold plate as a background. Fourier and Kramers-Krönig transformations of spectra were performed. Absorption bands were identified based on the works of Painter et al. (1981), Wang \& Griffiths (1985), Sobkowiak \& Painter (1992), Guo et al. (1996), Ibarra et al. (1996) as well as
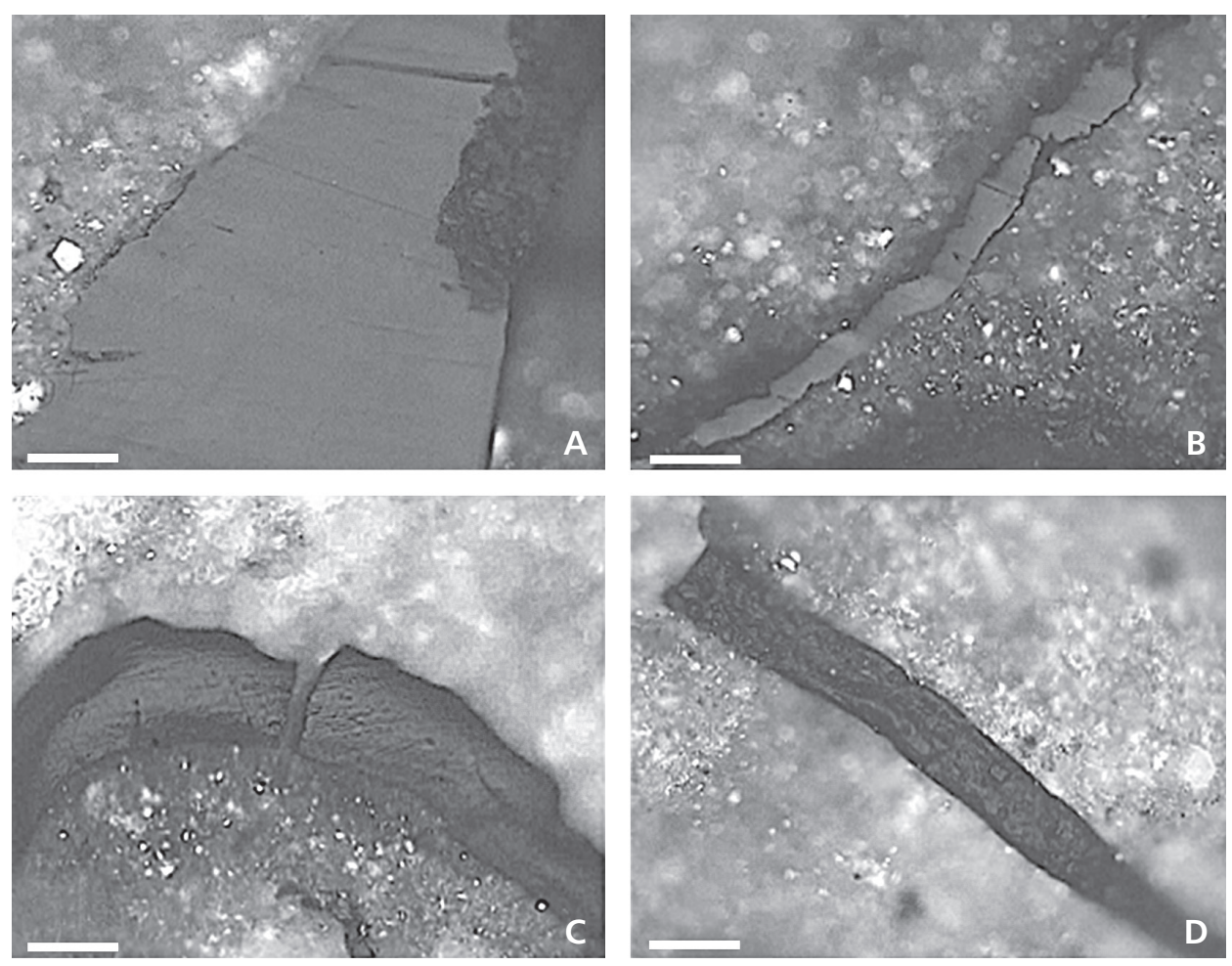

Figure 2. Microphotographs of graptolite periderm in the studied samples (section parallel to bedding, reflected light, immersion oil); A - sample P1, non-granular morphology with poorly visible lamellar structure; B - sample $\mathrm{P} 2$, non-granular morphology; C - sample B2, non-granular morphology; D - sample P2, granular morphology. 
Bustin \& Guo (1999). Curve-fitting procedure was employed regarding the aliphatic $\left(2800-3000 \mathrm{~cm}^{-1}\right)$ and $\mathrm{C}=\mathrm{O}+\mathrm{C}=\mathrm{C}\left(1500-1800 \mathrm{~cm}^{-1}\right)$ regions using GRAMS 32 software. The number of the bands and their initial positions were determined using the second derivative of the spectra and the data from the references (Painter et al. 1981; Wang \& Griffiths 1985; Lin \& Ritz 1993; Ibarra et al. 1996; Guo \& Bustin 1998a, b; Geng et al. 2009; Chen et al. 2012a). Combination of Lorentzian and Gaussian curves was applied. The goodness of fit was checked by the $\chi^{2}$ test. To demonstrate chemistry of the graptolite periderm the following ratios of the spectral band integration areas were used:

1) $\mathrm{CH}_{\mathrm{ar}}\left(3000-3100 \mathrm{~cm}^{-1}\right) /\left[\mathrm{CH}_{2}+\mathrm{CH}_{3}\left(2800-3000 \mathrm{~cm}^{-1}\right)\right]$, to show relative content of aromatic and aliphatic hydrogen functional groups i.e. aromaticity of the structure (Machnikowska et al. 2002, Lis et al. 2005, Chen et al. 2012a).

2) $\mathrm{CH}_{2}\left(2920-2940 \mathrm{~cm}^{-1}\right) / \mathrm{CH}_{3}\left(2955-2975 \mathrm{~cm}^{-1}\right)$, related to the of the length of aliphatic chains (Wang \& Griffiths 1985, Lin \& Ritz 1993, Ibarra et al. 1996, Guo $\&$ Bustin 1998a).

3) $\mathrm{C}=\mathrm{O}\left(1650-1800 \mathrm{~cm}^{-1}\right) / \mathrm{C}=\mathrm{C}_{\mathrm{ar}}\left(1500-1650 \mathrm{~cm}^{-1}\right)$ (Mastalerz \& Bustin 1996, 1997).

4) 'A' factor, a measure of the hydrocarbon-generating potential (Ganz \& Kalkreuth 1987), was determined as:

- 'A $\mathrm{A}_{1}$ ': $\left[\mathrm{CH}_{2}+\mathrm{CH}_{3}\left(3000-2800 \mathrm{~cm}^{-1}\right)\right] /\left[\mathrm{CH}_{2}+\mathrm{CH}_{3}\right.$ $\left.\left(3000-2800 \mathrm{~cm}^{-1}\right)+\mathrm{C}=\mathrm{C}\left(1630 \mathrm{~cm}^{-1}\right)\right]($ Chen et al. 2012a, b; Wang et al. 2013);

- ' $\mathrm{A}_{2}$ ': $\left[\mathrm{CH}_{2}+\mathrm{CH}_{3}\left(3000-2800 \mathrm{~cm}^{-1}\right)\right] /\left[\mathrm{CH}_{2}+\mathrm{CH}_{3}\right.$ $\left.\left(3000-2800 \mathrm{~cm}^{-1}\right)+\mathrm{C}=\mathrm{C}\left(1500-1650 \mathrm{~cm}^{-1}\right)\right]($ Guo \& Bustin 1998a, D'Angelo et al. 2010, Dutta et al. 2013).
5) ' $\mathrm{C}$ ' factor, being a proxy of the maturation level (Ganz \& Kalkreuth 1987), was calculated as:

- ' $\mathrm{C}_{1}{ }^{\prime}$ : $\mathrm{C}=\mathrm{O}\left(1710 \mathrm{~cm}^{-1}\right) /\left[\mathrm{C}=\mathrm{O}\left(1710 \mathrm{~cm}^{-1}\right)+\mathrm{C}=\mathrm{C}\right.$ $\left(1600 \mathrm{~cm}^{-1}\right)$ ] (Ganz \& Kalkreuth 1987; Chen et al. 2012a, b);

- ' $\mathrm{C}_{2}$ ': $\mathrm{C}=\mathrm{O}\left(1650-1800 \mathrm{~cm}^{-1}\right) /\left[\mathrm{C}=\mathrm{O}\left(1650-1800 \mathrm{~cm}^{-1}\right)\right.$ $+\mathrm{C}=\mathrm{C}\left(1500-1650 \mathrm{~cm}^{-1}\right)$ ] (Guo \& Bustin 1998a, D'Angelo et al. 2010, Dutta et al. 2013).

The ' $A$ ' and ' $C$ ' factors were determined by two methods to make it possible to compare the results with those given by different authors. Due to the presence of clay minerals, carbonates and quartz influencing the micro-FTIR spectra in the aromatic $\mathrm{CH}_{\mathrm{ar}}$ out-of-plane deformation region $\left(750-900 \mathrm{~cm}^{-1}\right)$, this band was not taken into account in calculation of the spectral ratios.

\section{Results and discussion}

Graptolite particles under reflected light show two types of morphology: non-granular (Fig. 2A-C), which predominates, and granular - rarely observed (Fig. 2D). Non-granular fragments sometimes display, poorly visible, lamellar structure, typical for the fusellar tissue (Goodarzi 1984; Goodarzi \& Norford 1985, 1987; Bustin et al. 1989), (Fig. 2A). Granular fragments (Fig. 2D) probably compose the common canal (Goodarzi 1984; Goodarzi \& Norford 1985, 1987; Bustin et al. 1989), which is sometimes filled with fine-grained pyrite.

The mean values of graptolite reflectance $\left(\mathrm{R}_{\mathrm{r}}\right)$ range between $0.70 \%$ and $0.77 \%(\mathrm{~s}=0.07-0.08 \%)$ (Tab. 1), indicating maturity corresponding to the oil window

Table 1. Mean reflectance (Rr), Vitrinite Reflectance Equivalent (VRE) and the selected micro-FTIR spectral parameters of the graptolite periderm.

\begin{tabular}{lcccccccccc}
\hline Sample & $\mathrm{R}_{\mathrm{r}}[\%]$ & $\mathrm{VRE}[\%]$ & $\mathrm{CH}_{\mathrm{ar}} /\left(\mathrm{CH}_{2}+\mathrm{CH}_{3}\right)$ & $\mathrm{CH}_{2} / \mathrm{CH}_{3}$ & $\mathrm{C}=\mathrm{O} / \mathrm{C}=\mathrm{C}$ & ${ }^{\prime} \mathrm{A}_{1}{ }^{\prime}$ & & ${ }^{\prime} \mathrm{A}_{2}{ }^{\prime}$ & ${ }^{\prime} \mathrm{C}_{1}{ }^{\prime}$ & ${ }^{\prime} \mathrm{C}_{2}{ }^{\prime}$ \\
\hline $\mathrm{P} 1$ & 0.70 & 0.67 & 0.050 & 2.08 & 0.44 & 0.79 & 0.60 & 0.22 & 0.31 \\
$\mathrm{n}=42$ & 0.07 & & 0.011 & 0.28 & 0.21 & 0.09 & 0.10 & 0.11 & 0.10 \\
\hline $\mathrm{P} 2$ & 0.74 & 0.70 & 0.058 & 1.97 & 0.41 & 0.76 & 0.57 & 0.29 & 0.29 \\
$\mathrm{n}=54$ & 0.08 & & 0.012 & 0.18 & 0.11 & 0.09 & 0.08 & 0.12 & 0.06 \\
\hline $\mathrm{B} 1$ & 0.74 & 0.70 & 0.055 & 2.06 & 0.48 & 0.46 & 0.28 & 0.29 & 0.33 \\
$\mathrm{n}=45$ & 0.07 & & 0.017 & 0.31 & 0.15 & 0.15 & 0.13 & 0.11 & 0.06 \\
\hline $\mathrm{B} 2$ & 0.77 & 0.72 & 0.054 & 1.62 & 0.51 & 0.49 & 0.29 & 0.37 & 0.32 \\
$\mathrm{n}=32$ & 0.07 & & 0.021 & 0.15 & 0.12 & 0.18 & 0.09 & 0.15 & 0.07 \\
\hline
\end{tabular}

Abbreviations: $\mathrm{Rr}$ - mean reflectance of the graptolite periderm; VRE - Vitrinite Reflectance Equivalent; $\mathrm{CH}_{\mathrm{ar}} /\left(\mathrm{CH}_{2}+\mathrm{CH}_{3}\right)-$ relative content of the aromatic (3000-3100 $\left.\mathrm{cm}^{-1}\right)$ and aliphatic $\left(2800-3000 \mathrm{~cm}^{-1}\right)$ hydrogen functional groups; $\mathrm{CH}_{2} / \mathrm{CH}_{3}$ - relative intensity of the $\mathrm{CH}_{2}\left(2920-2940 \mathrm{~cm}^{-1}\right)$ and $\mathrm{CH}_{3}\left(2955-2975 \mathrm{~cm}^{-1}\right)$ bands; $\mathrm{C}=\mathrm{O} / \mathrm{C}=\mathrm{C}$ - relative content of the $\mathrm{C}=\mathrm{O}$ groups $\left(1650-1800 \mathrm{~cm}^{-1}\right)$ and $\mathrm{C}=\mathrm{C}$ aromatic rings $\left(1500-1650 \mathrm{~cm}^{-1}\right)$; 'A1' - the 'A' factor calculated as $\left[\mathrm{CH}_{2}+\mathrm{CH}_{3}\left(3000-2800 \mathrm{~cm}^{-1}\right)\right] /\left[\mathrm{CH}_{2}+\mathrm{CH}_{3}\left(3000-2800 \mathrm{~cm}^{-1}\right)+\mathrm{C}=\mathrm{C}\left(1630 \mathrm{~cm}^{-1}\right)\right]$; 'A2' - the 'A' factor calculated as $\left[\mathrm{CH}_{2}+\mathrm{CH}_{3}\left(3000-2800 \mathrm{~cm}^{-1}\right)\right] /\left[\mathrm{CH}_{2}+\mathrm{CH}_{3}\left(3000-2800 \mathrm{~cm}^{-1}\right)+\mathrm{C}=\mathrm{C}\left(1500-1650 \mathrm{~cm}^{-1}\right)\right]$; 'C1' - the ' $\mathrm{C}$ ' factor calculated as $\mathrm{C}=\mathrm{O}\left(1710 \mathrm{~cm}^{-1}\right) /\left[\mathrm{C}=\mathrm{O}\left(1710 \mathrm{~cm}^{-1}\right)+\mathrm{C}=\mathrm{C}\left(1600 \mathrm{~cm}^{-1}\right)\right] ;{ }^{\prime} \mathrm{C} 2$ ' - the ' $\mathrm{C}$ ' factor calculated as $\mathrm{C}=\mathrm{O}\left(1650-1800 \mathrm{~cm}^{-1}\right) /\left[\mathrm{C}=\mathrm{O}\left(1650-1800 \mathrm{~cm}^{-1}\right)+\mathrm{C}=\mathrm{C}\right.$ $\left.\left(1500-1650 \mathrm{~cm}^{-1}\right)\right] ; \mathrm{n}$ - number of measurements; italics - the standard deviation is given. 
zone. Relatively low number of measurements (32-54) is due to the limited amount of homogenous areas on the graptolite particles. The Vitrinite Reflectance Equivalent (VRE) values, calculated after Petersen et al. (2013), vary from $0.67 \%$ to $0.72 \%$ (Tab. 1 ). The results of $\mathrm{R}_{\mathrm{r}}$ measurements conform to the data presented by Smolarek et al. (2014). Similar or higher values were obtained by Schito et al. (2017). The results are also in line with the $\mathrm{T}_{\max }$ determinations $\left(431-441^{\circ} \mathrm{C}\right)$ made by Smolarek et al. (2014), Mustafa et al. (2015) and Schito et al. (2017). The oil window zone is also confirmed by the occurrence of scarce oil droplets, which reveal spherical shape and yellow colour under the fluorescent light.

Several bands of absorption are displayed in a typical micro-FTIR spectrum of the graptolite periderm (Fig. 3). They are assigned to $\mathrm{OH}$ groups $\left(3400-3580 \mathrm{~cm}^{-1}\right)$, aromatic $\mathrm{CH}_{\mathrm{ar}}$ stretching vibrations $\left(3000-3100 \mathrm{~cm}^{-1}\right)$, and aliphatic $\mathrm{CH}_{2}+\mathrm{CH}_{3}$ stretching vibrations (2800-3000 $\left.\mathrm{cm}^{-1}\right)$. Curve-fitting procedure revealed the occurrence of six or seven bands within the aliphatic region (Fig. 4): 2985-2990 $\mathrm{cm}^{-1}$ - symmetric stretching vibrations of $\mathrm{CH}$ groups (very weak, found only in some of the spectra); 2955-2960 $\mathrm{cm}^{-1}$ - asymmetric stretching vibrations of $\mathrm{CH}_{3}$ groups; 2920-2930 $\mathrm{cm}^{-1}$ - asymmetric stretching vibrations of $\mathrm{CH}_{2}$ groups; $2890-2905 \mathrm{~cm}^{-1}-$ stretching vibrations of CH groups; 2865-2875 $\mathrm{cm}^{-1}$ symmetric stretching vibrations of $\mathrm{CH}_{3}$ groups; $2845-2855$ $\mathrm{cm}^{-1}-$ symmetric stretching vibrations of $\mathrm{CH}_{2}$ groups;

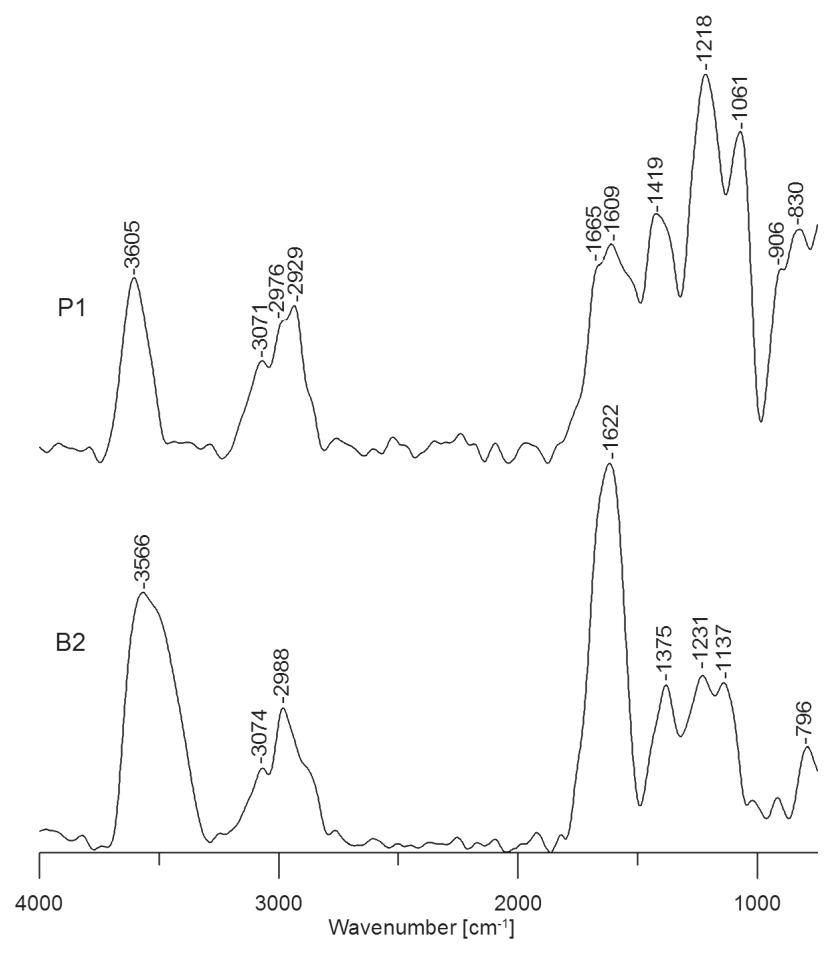

Figure 3. Representative micro-FTIR spectra of the graptolite periderm (samples P1 and B2).

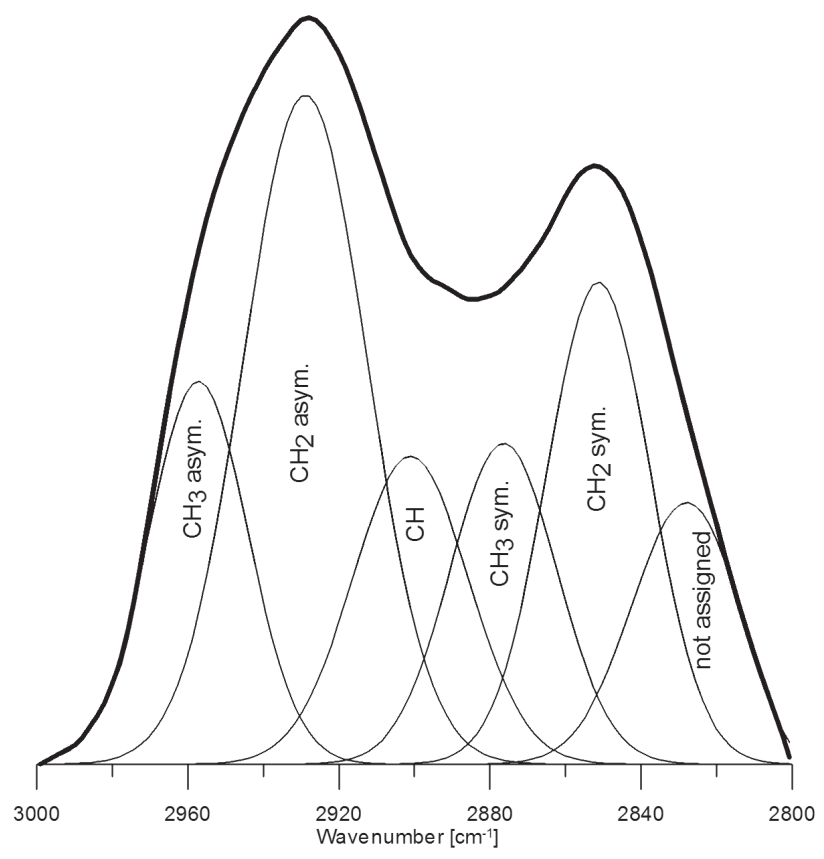

Figure 4. Curve-fitting of the aliphatic $\left(2800-3000 \mathrm{~cm}^{-1}\right)$ region for sample (sample P1).

2825-2830 $\mathrm{cm}^{-1}-$ a very weak band, not assigned (Ibarra et al. 1996).

Six bands of absorption were identified in the $\mathrm{C}=\mathrm{O}+$ $\mathrm{C}=\mathrm{C}$ region (1500-1800 $\mathrm{cm}^{-1}$ ) (Fig. 5): $1760-1765 \mathrm{~cm}^{-1}-$ $\mathrm{C}=\mathrm{O}$ stretching vibrations of esters; $1710-1715 \mathrm{~cm}^{-1}$ $\mathrm{C}=\mathrm{O}$ stretching vibrations of carboxylic acids; $1660-1670$ $\mathrm{cm}^{-1}$ - conjugated $\mathrm{C}=\mathrm{O}$ stretching vibrations (quinones and ketones) $1615-1620 \mathrm{~cm}^{-1}, 1570-1580 \mathrm{~cm}^{-1}$ and $1535-1545 \mathrm{~cm}^{-1}-\mathrm{C}=\mathrm{C}$ aromatic ring stretching vibrations.

In addition, bands assigned to aliphatic $\mathrm{CH}_{2}+\mathrm{CH}_{3}$ deformation $\left(\sim 1350-1470 \mathrm{~cm}^{-1}\right)$, aromatic ether, ester or phenolic $\mathrm{C}-\mathrm{O}$ stretching vibrations $\left(\sim 1100-1300 \mathrm{~cm}^{-1}\right)$, aliphatic ether $\mathrm{C}-\mathrm{O}$ stretching vibrations $(\sim 1030-1080$ $\mathrm{cm}^{-1}$ ), and aromatic $\mathrm{CH}_{\mathrm{ar}}$ out-of-plane deformation $\left(\sim 750-900 \mathrm{~cm}^{-1}\right)$ are observed. Bands corresponding to clay minerals (illite, kaolinite) $\left(\sim 1000-1150 \mathrm{~cm}^{-1}\right.$ and $\left.\sim 900 \mathrm{~cm}^{-1}\right)$, carbonates (mostly calcite) $(\sim 1430-1440$ $\mathrm{cm}^{-1}$ and $\left.\sim 880 \mathrm{~cm}^{-1}\right)$, quartz $\left(\sim 1050-1100 \mathrm{~cm}^{-1}\right.$ and $\left.\sim 780-800 \mathrm{~cm}^{-1}\right)$, as well as pyrite $\left(\sim 1000-1150 \mathrm{~cm}^{-1}\right)$ (Chen et al. 2014, 2015) are also detected.

The $\mathrm{CH}_{\mathrm{ar}} /\left(\mathrm{CH}_{2}+\mathrm{CH}_{3}\right)$ ratio reaches $0.050-0.058$ (Tab. 1, Fig. 6), being higher than the values determined for the Silurian graptolites from the Baltic Basin of Northern Poland of similar (Caricchi et al. 2016) or even higher reflectance (Morga \& Kamińska 2018). The $\mathrm{CH}_{2} /$ $\mathrm{CH}_{3}$ ratio decreases from 2.08 to 1.62 with the increasing reflectance, which demonstrates shortening of the aliphatic chains (Tab. 1, Fig. 7). These values correspond well with the ones determined for the Silurian graptolites 


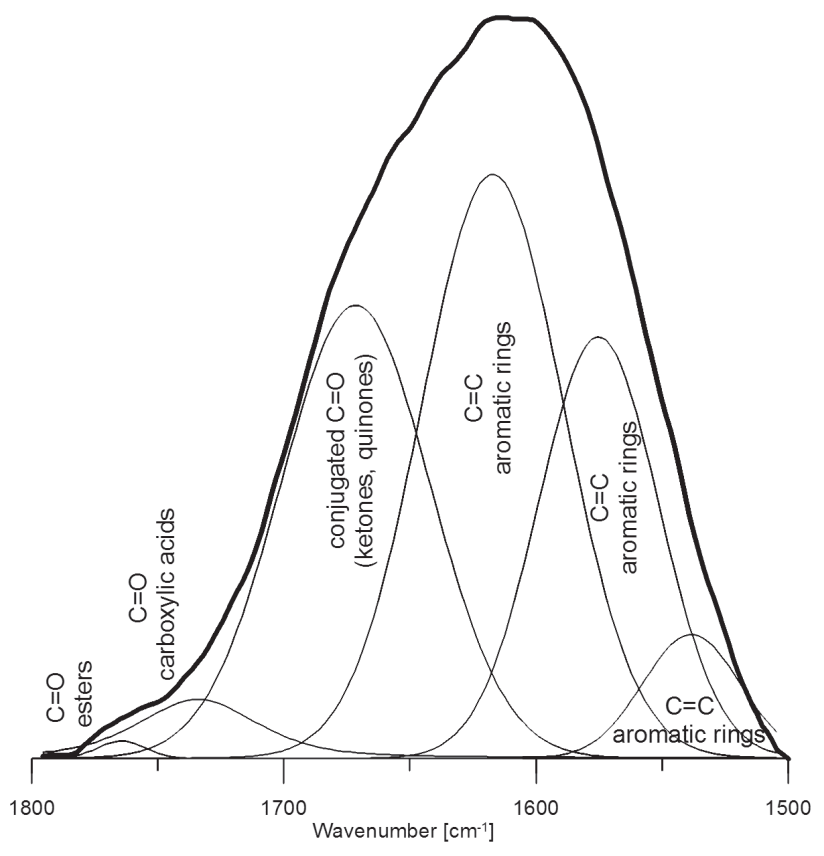

Figure 5. Curve-fitting of the $\mathrm{C}=\mathrm{O}+\mathrm{C}=\mathrm{C}\left(1500-1800 \mathrm{~cm}^{-1}\right)$ region for sample (sample B2).

(Suchý et al. 2002, 2004; Caricchi et al. 2016) as well as chitinozoans and scolecodonts (Dutta et al. 2013). Much lower values were observed in graptolites showing higher reflectance (Morga \& Kamińska 2018). The $\mathrm{C}=\mathrm{O} / \mathrm{C}=\mathrm{C}$ ratio is low $(0.41-0.51)$ which reveals that weathering did not affect the chemical structure of the graptolite

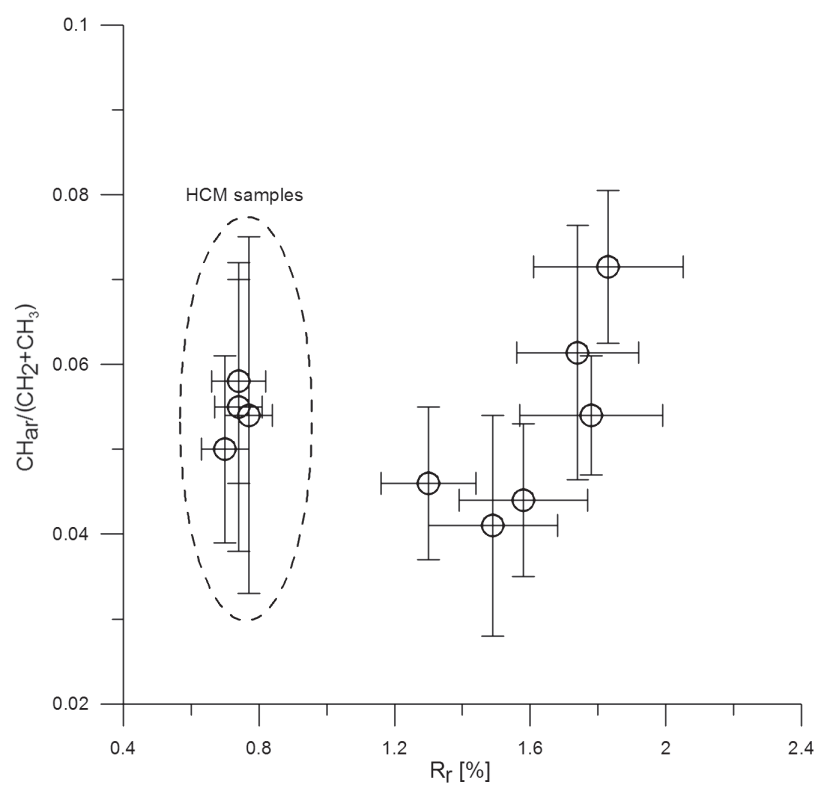

Figure 6. Relationship between the $\mathrm{CH}_{\mathrm{ar}} /\left(\mathrm{CH}_{2}+\mathrm{CH}_{3}\right)$ ratio and the mean reflectance $\left(\mathrm{R}_{\mathrm{r}}\right)$ of the graptolite periderm (data referring to $\mathrm{R}_{\mathrm{r}}=1.30-1.83 \%$ after Morga \& Kamińska 2018). periderm (Tab. 1). In general, the ratio is lower in comparison to the graptolites having higher reflectance and examined from the core samples (Morga \& Kamińska 2018). The ' $A_{1}$ ' factor varies between 0.46 and 0.79 , while the ' $\mathrm{A}_{2}$ ' factor between 0.28 and 0.60 (Tab. 1). Much higher values indicating higher hydrocarbon potential are observed regarding the samples from the Praqgowiec ravine. Comparable results were gained for graptolites (Caricchi et al. 2016, Morga \& Kamińska 2018), chitinozoans and scolecodonts (Dutta et al. 2013).

The ' $\mathrm{C}_{1}$ ' factor changes from 0.22 to 0.37 and the ' $\mathrm{C}_{2}$ ' factor from 0.29 to 0.33 (Tab. 1), falling within the ranges documented for the higher reflectance graptolites (Morga \& Kamińska 2018), and being lower than those found by Caricchi et al. (2016). In general, these values are similar to those obtained for chitinozoans and scolecodonts (Dutta et al. 2013). Considering the ' $\mathrm{A}_{2}$ ' and ' $\mathrm{C}_{2}$ ' factors (Guo \& Bustin 1998a, D'Angelo et al. 2010), the graptolite periderm represents kerogen type II or III (or can be treated as transitive type II/III) (Fig. 8), as was found in the previous studies (Bustin et al. 1989, Morga \& Kamińska 2018).

The graptolite periderm in the studied samples is composed predominantly of aromatic groups and rings with lesser amount of aliphatic and carbonyl/carboxyl groups. The $\mathrm{CH}_{2} / \mathrm{CH}_{3}$ ratio indicates that aliphatic chains are relatively long in comparison to vitrinites and liptinites from coals (Guo \& Bustin 1998a, Lin \& Ritz 1993, Mastalerz \& Bustin 1996, Komorek 2016, among others).

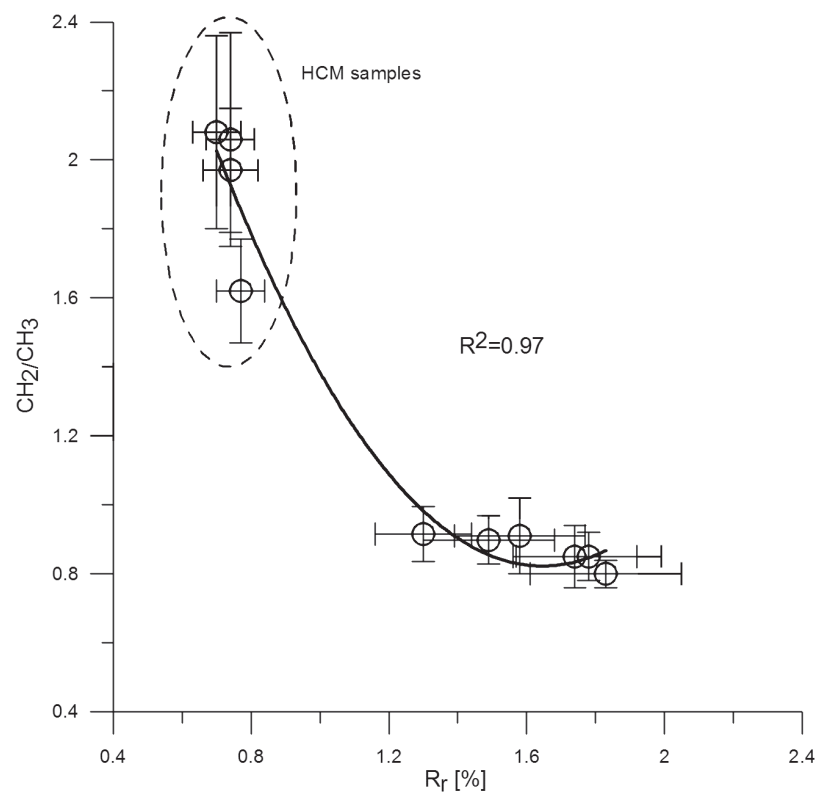

Figure 7. Relationship between the $\mathrm{CH}_{2} / \mathrm{CH}_{3}$ ratio and the mean reflectance $\left(\mathrm{R}_{\mathrm{r}}\right)$ of the graptolite periderm (data referring to $\mathrm{R}_{\mathrm{r}}=1.30-1.83 \%$ after Morga \& Kamińska 2018). 


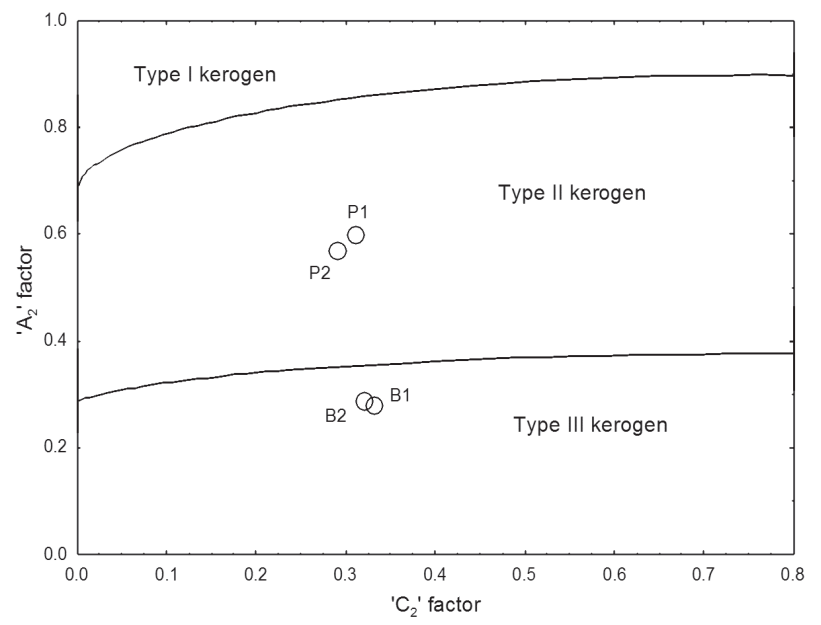

Figure 8. Kerogen type diagram of the graptolite periderm according to ' $\mathrm{A}_{2}$ ' and ' $\mathrm{C}_{2}$ ' factors obtained from the micro-FTIR spectra (after Guo \& Bustin 1998a, D’Angelo et al. 2010).

The results obtained for the two analysed localities (Prągowiec ravine, Bardo Stawy) are mostly consistent. The only distinct difference is in the ' $\mathrm{A}_{1}$ ' and ' $\mathrm{A}_{2}$ ' factors, higher values of which indicate much higher hydrocarbon potential of shales collected in the Prągowiec ravine, even though the reflectance values are similar. It should be mentioned, however, that the 'A' factor does not show close relationship with thermal maturity indices such as $\mathrm{R}_{\mathrm{r}}$ or $\mathrm{T}_{\max }$, as was revealed from shale studies (Mroczkowska-Szerszeń et al. 2015, Caricchi et al. 2016).

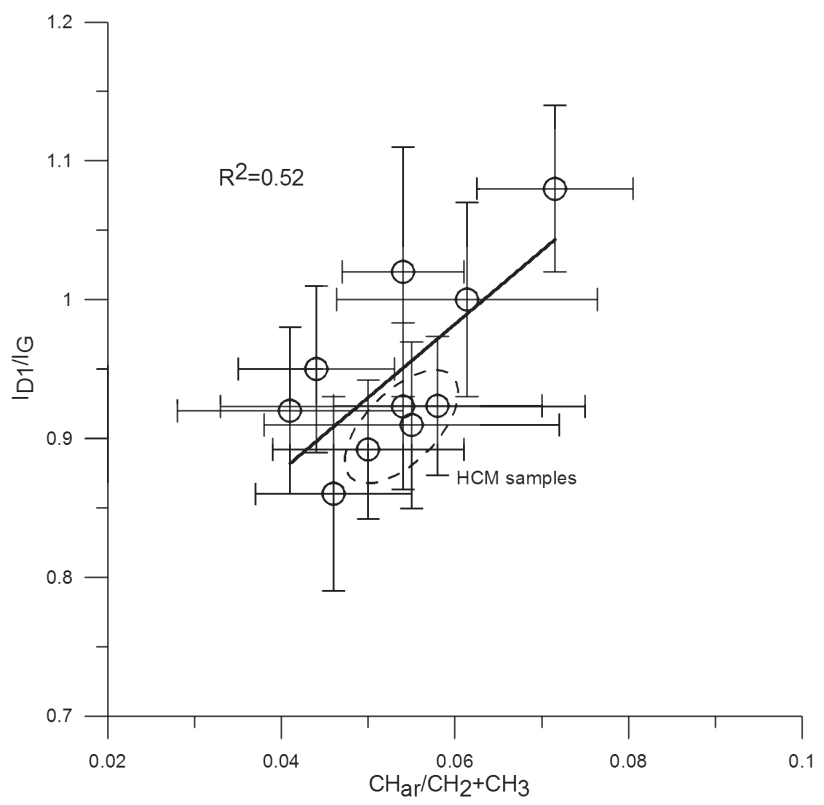

Figure 9. Relationship between the $\mathrm{I}_{\mathrm{D} 1} / \mathrm{I}_{\mathrm{G}}$ ratio and the the $\mathrm{CH}_{\mathrm{ar}} /\left(\mathrm{CH}_{2}+\right.$ $\mathrm{CH}_{3}$ ) ratio for the graptolite periderm (data referring to $\mathrm{R}_{\mathrm{r}}=1.30-1.83 \%$ after Morga \& Kamińska 2018).
Besides, chemical features of the graptolite periderm may not fully reflect the hydrocarbon potential of the whole rock. Furthermore, TOC content in shales occurring in both localities is very varied. It ranges from $0.3 \%$ to $2.0 \%$ for Bardo Stawy and from $0.5 \%$ to $1.2 \%$ for the Prągowiec ravine (Mustafa et al. 2015, Schito et al. 2017). This means that the values of some geochemical parameters are dependent on the place of sampling in the rock profile of the two studied localities.

Many similarities between chemical structure of the graptolite periderm and vitrinite of the adequate rank (Vitrinite Reflectance Equivalent - VRE was used for comparison) are well-established. This regards principally the $\mathrm{CH}_{\mathrm{ar}} /\left(\mathrm{CH}_{2}+\mathrm{CH}_{3}\right)$ ratio (Machnikowska et al. 2002, Chen et al. 2012a) and the $\mathrm{CH}_{2} / \mathrm{CH}_{3}$ ratio (Lis et al. 2005, Petersen \& Nytoft 2006, Chen et al. 2012a), the ' $\mathrm{A}_{1}$ ' factor (Chen et al. 2012a). Such relation was previously suggested by Bustin et al. (1989) and Morga \& Kamińska (2018). To some extent it is also indicated by the kerogen type of the graptolite periderm, which is frequently detected as transitive - II/III, although typical marine kerogen is of type II, and type III (represented by vitrinite) represents a terrestrial origin.

It is observed that within the whole graptolite reflectance range $\left(\mathrm{R}_{\mathrm{r}}=0.70-1.83 \%\right)$ analysed in this and previous study (Morga \& Kamińska 2018) the $\mathrm{CH}_{\mathrm{ar}} /\left(\mathrm{CH}_{2}+\right.$ $\mathrm{CH}_{3}$ ) ratio stays stable and begins to increase only at higher reflectance $\left(\mathrm{R}_{\mathrm{r}}>1.6 \%\right)$, showing weak increase in aromaticity (Fig. 6). On the other hand, the $\mathrm{CH}_{2} / \mathrm{CH}_{3}$ ratio strongly decreases with increasing $R_{r}$, which reflects

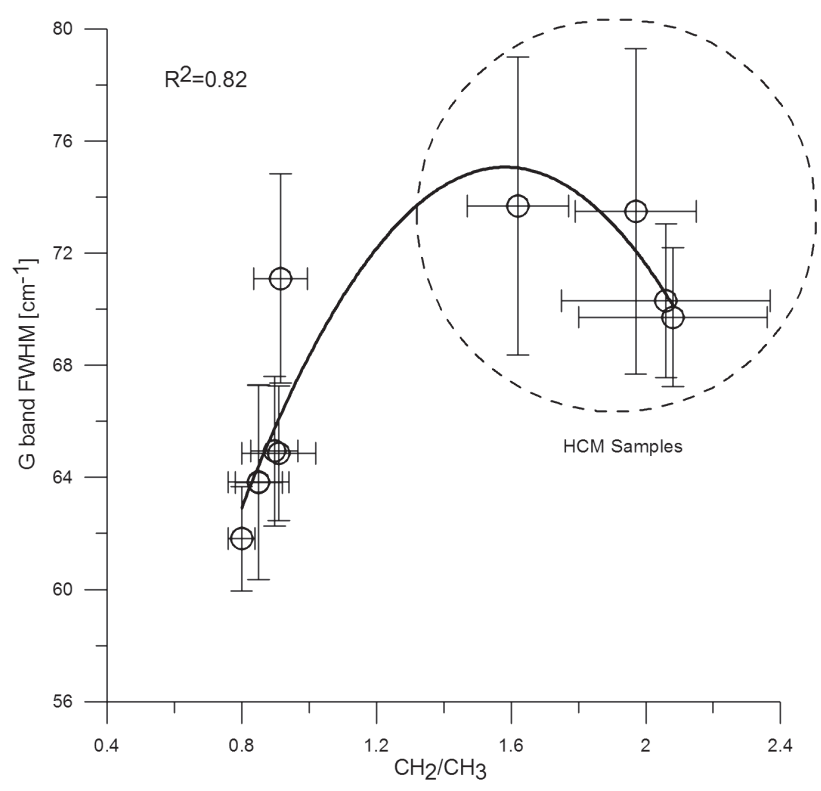

Figure 10. Relationship between the $\mathrm{G}$ band FWHM and the the $\mathrm{CH}_{2} / \mathrm{CH}_{3}$ ratio for the graptolite periderm (data referring to $\mathrm{R}_{\mathrm{r}}=1.30-1.83 \%$ after Morga \& Kamińska 2018). 
shortening of the aliphatic chains (Fig. 7). Adequate relationship was found for vitrinite (Chen et al. 2012a).

The microstructural examination showed that the graptolite periderm from the Holy Cross Mountains is a poorly organized carbonaceous matter (Morga 2019). The study also proved that microstructure does not vary significantly between the samples from the two considered localities. The micro-FTIR derived spectral ratios can be compared to the micro-Raman spectral parameters obtained on the same sample set (Morga \& Pawlyta 2018, Morga 2019). It is seen that aromaticity of the graptolite periderm, demonstrated by the $\mathrm{CH}_{\mathrm{ar}} /\left(\mathrm{CH}_{2}+\mathrm{CH}_{3}\right)$ ratio, tends to increase with the increasing $\mathrm{I}_{\mathrm{D} 1} / \mathrm{I}_{\mathrm{G}}$ ratio (Fig. 9), which is a measure of the diameter of the coherent domains $\left(\mathrm{L}_{\mathrm{a}}\right)$ in the carbonaceous materials (Tuinstra \& Koenig 1970, Ferrari \& Robertson 2000 among others). The $\mathrm{I}_{\mathrm{D} 1} / \mathrm{I}_{\mathrm{G}}$ ratio increases with increasing $L_{a}$, when it is below $2 \mathrm{~nm}$ (which is the case here - see Morga \& Pawlyta 2018), and decreases when $\mathrm{L}_{\mathrm{a}}$ exceeds $2 \mathrm{~nm}$ (Ferrari \& Robertson 2000). At $\mathrm{CH}_{2} / \mathrm{CH}_{3}=1.3$, the full width at half maximum (FWHM) of the Raman G band, which arises from the $\mathrm{E}_{2 \mathrm{~g}}$ stretching vibrations in aromatic layers (Beyssac et al. 2003), begins to decrease with decreasing $\mathrm{CH}_{2} / \mathrm{CH}_{3}$ ratio (Fig. 10), which reflects improvement in the structural ordering (Kelemen \& Fang 2001, Quirico et al. 2005). Therefore, it can be concluded that with increasing $R_{r}$ the graptolite periderm (similarly to vitrinite) undergoes significant chemical and microstructural alteration. The aromaticity increases and the aliphatic chains become shorter. This is accompanied by growth of the coherent domains and increase in the structural order.

\section{Conclusions}

Graptolite periderm in the Silurian shales from the Holy Cross Mountains of Poland $\left(\mathrm{R}_{\mathrm{r}}=0.70-0.77 \%\right.$; $\mathrm{VRE}=0.67-$ $0.72 \%$ ) is composed predominantly of aromatic groups and rings with lesser amount of aliphatic and carbonyl/ carboxyl groups. Chemical composition does not vary significantly between the samples from the two considered localities (the Praqgowiec ravine and Bardo Stawy), which corresponds to the narrow range of graptolite reflectance. However, the samples from the Prągowiec ravine are characterized by higher hydrocarbon potential. It is found that many similarities occur in the chemical structure of the graptolite periderm and vitrinite within the reflectance range of $\mathrm{R}_{\mathrm{r}} \approx 0.7-1.5 \%$. With increasing reflectance, the length of the aliphatic chains (as inferred from the $\mathrm{CH}_{2} /$ $\mathrm{CH}_{3}$ ratio) in the graptolite periderm decreases, and the relative content of the aromatic groups [as indicated by the $\mathrm{CH}_{\mathrm{ar}} /\left(\mathrm{CH}_{2}+\mathrm{CH}_{3}\right)$ ratio] begins to increase at $\mathrm{R}_{\mathrm{r}} \approx 1.6 \%$. This is accompanied by growth of the coherent domains and improvement in the structural order.

\section{References}

Beyssac, O., Goffe, B., Petitet, J.P., Froigneux, E., Moreau, M. \& RouzAud, J.N. 2003. On the characterization of disordered and heterogenous carbonaceous materials by Raman spectroscopy. Spectrochimica Acta Part A 59, 2267-2276. DOI 10.1016/S1386-1425(03)00070-2

Bustin, R.M. \& Guo, Y. 1999. Abrupt changes (jumps) in reflectance values and chemical compositions of artificial charcoals and inertinite in coals. International Journal of Coal Geology 38, 237-260. DOI 10.1016/S0166-5162(98)00025-1

Bustin, R.M., Link, C. \& Goodarzi, F. 1989. Optical properties and chemistry of graptolite periderms following laboratory simulated maturation. Organic Geochemistry 14, 355-364. DOI 10.1016/0146-6380(89)90001-6

Caricchi, C., Corrado, S., Di Paolo, L., Aldega, L. \& Grigo, D. 2016. Thermal maturity of Silurian deposits in the Baltic Syneclise (on-shore Polish Baltic Basin): contribution to unconventional resources assessment. Italian Journal of Geosciences 135, 383-393. DOI 10.3301/IJG.2015.16

Chen, Y., Mastalerz, M. \& Schimmmelmann, A. $2012 \mathrm{a}$. Characterization of chemical functional groups in macerals across different coal ranks via micro-FTIR spectroscopy. International Journal of Coal Geology 104, 22-33.

DOI 10.1016/j.coal.2012.09.001

Chen, Y., Caro, L.D., Mastalerz, M., Schimmmelmann, A. \& Blandon, A. 2012b. Mapping the chemistry of resinite, funginite and associated vitrinite in coal with micro-FTIR. Journal of Microscopy 249, 69-81. DOI 10.1111/j.1365-2818.2012.03685.x

Chen, Y., Furmann, A., Mastalerz, M. \& Schimmmelmann, A. 2014. Quantitative analysis of shales by $\mathrm{KBr}-F T I R$ and microFTIR. Fuel 116, 538-549. DOI 10.1016/j.fuel.2013.08.052

Chen, Y., Zou, C., Mastalerz, M., Hu, S., Gasaway, C. \& Tao, X. 2015. Applications of Micro-Fourier Transform Infrared Spectroscopy (FTIR) in the Geological Sciences-A Review. International Journal of Molecular Sciences 16, 3022330250.

DOI 10.3390/ijms161226227

Cole, G.A. 1994. Graptolite-chitinozoan reflectance and its relationship to other geochemical maturity indicators in the Silurian Qusaiba Shale, Saudi Arabia. Energy \& Fuels 8, 1443-1459. DOI 10.1021/ef00048a035

D’Angelo, J., Zodrow, E. \& Camargo, A. 2010. Chemometric study of functional groups in Pennsylvanian gymnosperm plant organs (Sydney Coalfield, Canada): Implications for chemotaxonomy and assessment of kerogen formation. Organic Geochemistry 41, 1312-1325.

DOI 10.1016/j.orggeochem.2010.09.010

Dutta, S., Hartkopf-Fröder, C., Witte, K., Brocke, R. \& Mann, U. 2013. Molecular characterization of fossil palynomorphs by transmission micro-FTIR spectroscopy: Implications for hydrocarbon source evaluation. International Journal of Coal Geology 115, 13-23. DOI 10.1016/j.coal.2013.04.003

Ferrari, A.C. \& Robertson, J. 2000. Interpretation of Raman spectra of disordered and amorphous carbon. Physical Review B 61, 14095-14107. DOI 10.1103/PhysRevB.61.14095 
Ganz, H. \& Kalkreuth, W. 1987. Application of infrared spectroscopy to the classification of kerogen-types and the evaluation of source rock and oil shale potentials. Fuel 66, 708-711. DOI 10.1016/0016-2361(87)90285-7

Geng, W., Nakajima, T., Takanashi, H. \& Ohki, A. 2009. Analysis of carboxyl group in coal and coal aromaticity by Fourier transform infrared (FT-IR) spectrometry. Fuel 88, 139-144. DOI 10.1016/j.fuel.2008.07.027

GoodARZI, F. 1984. Organic petrography of graptolite fragments from Turkey. Marine and Petroleum Geology 1, 202-210. DOI 10.1016/0264-8172(84)90146-6

GoodARZI, F. 1985. Dispersion of optical properties of graptolite periderms with increased maturity in early Paleozoic sediments. Fuel 64, 1735-1740.

DOI 10.1016/0016-2361(85)90401-6

Goodarzi, F. \& Norford, B.S. 1985. Graptolites as indicator of the temperature histories of rocks. Journal of Geological Society London 142, 1089-1099.

DOI 10.1144/gsjgs.142.6.1089

Goodarzi, F. \& Norford, B.S. 1987. Optical properties of graptolite periderm - a review. Bulletin of Geological Society Denmark 35, 141-147.

Goodarzi, F. \& Norford, B.S. 1989. Variation of graptolite reflectance with depth of burial. International Journal of Coal Geology 11, 127-141.

DOI 10.1016/0166-5162(89)90002-5

Guo, Y. \& Bustin, R.M. 1998a. Micro-FTIR spectroscopy of liptinite macerals in coal. International Journal of Coal Geology 36, 259-275. DOI 10.1016/S0166-5162(97)00044-X

Guo, Y. \& Bustin, R.M. 1998b. FTIR spectroscopy and reflectance of modern charcoals and fungal decayed woods: implications for studies of inertinite in coals. International Journal of Coal Geology 37, 29-53.

DOI 10.1016/S0166-5162(98)00019-6

Guo, Y., Renton, J.J. \& Penn, J.H. 1996. FTIR microspectroscopy of particular liptinite- (lopinite-) rich, Late Permian coals from Southern China. International Journal of Coal Geology 29, 187-197. DOI 10.1016/0166-5162(95)00024-0

Ibarra, J.V., Munoz, E. \& Moliner, R. 1996. FTIR study of the evolution of coal structure during the coalification process. Organic Geochemistry 24, 725-735.

DOI 10.1016/0146-6380(96)00063-0

ISO 7404-5 2009. Methods for the Petrographic Analysis of Coals - Part 5: Method of Determining Microscopically the Reflectance of Vitrinite. International Organization for Standardization.

JARVIE, D.M. 2012. Shale resource systems for oil and gas: part 1 shale-gas resource systems. American Association of Petroleum Geologists Memoir 97, 69-87.

Kelemen, S.R. \& Fang, H.R. 2001. Maturity trends in Raman spectra from kerogen and coals. Energy \& Fuels 14, 653-658. DOI 10.1021/ef0002039

KomoreK, J. 2016. Internal structure of vitrinite and sporinite in the view of micro-FTIR spectroscopy using the example of coal from the seam 405 (USCB). Archives of Mining Sciences 61, 729-748. DOI 10.1515/amsc-2016-0050

Kremer, B. 2001. Acritarchs from the Upper Ordovician of southern Holy Cross Mountains, Poland. Acta Palaeontologica Polonica 46, 595-601.

Lin, R. \& Ritz, P. 1993. Studying the chemistry of individual macerals using IR microspectroscopy, and the structural implications on oil vs. gas/condensate proneness and 'lowrank' generation. Organic Geochemistry 20, 695-706.

DOI 10.1016/0146-6380(93)90055-G

Link, C.M., Bustin, R.M. \& Goodarzi, F. 1990. Petrology of graptolites and their utility as indices of thermal maturity in Lower Paleozoic strata in northern Yukon, Canada. International Journal of Coal Geology 15, 113-135. DOI 10.1016/0166-5162(90)90007-L

Lis, G.P., Mastalerz, M., Schimmmelmann, A., Lewan, M.D. \& STANKIEWICZ, B.A. 2005. FTIR absorption indices for thermal maturity in comparison with vitrinite reflectance $\mathrm{R}_{\mathrm{o}}$ in type-II kerogens from Devonian black shales. Organic Geochemistry 36, 1533-1552. DOI 10.1016/j.orggeochem.2005.07.001

Luo, Q., Goodarzi, F., Zhong, N., Wang, Y., Qiu, N., Skovsted, C.B., Suchý, V., Schovsbo, N.H., Morga, R., Xu, Y., Hao, J., Liu, A., Wu, J., CaO, W. , Min, X. \& Wu, J. 2020. Graptolites as fossil geo-thermometers and source material of hydrocarbons: An overview of four decades of progress. Earth-Science Reviews 200, art. 103000.

DOI 10.1016/j.earscirev.2019.103000

Machnikowska, H., Krztoń, A. \& Machnikowski, J. 2002. The characterization of coal macerals by diffuse reflectance infrared spectroscopy. Fuel 81, 245-252.

DOI 10.1016/S0016-2361(01)00125-9

Maletz, J. 2017. Graptolite Paleobiology. Topics in Palaeobiology. 323 pp. Wiley-Blackwell. DOI 10.1002/9781118515624

Maletz, J., Bates, D.E.B., Brussa, E.D., Cooper, R.A., Lenz, A.C., Riva, J.F., Toro, B.A. \& Zhang, Y.D. 2014. Treatise on Invertebrate Paleontology, Part V, revised. Chapter 12: Glossary of the Hemichordata. Treatise Online 62, 1-23. DOI 10.17161/to.v0i0.4710

Masiak, M., Podhalańska, T. \& Stempień-Salek, M. 2003. Ordovician-Silurian boundary in the Bardo Syncline, Holy Cross Mountains, Poland - new data on fossil assemblages and sedimentary succession. Geological Quarterly 47, 311-330.

Mastalerz, M. \& Bustin, R.M. 1996. Application of reflectance micro-Fourier Transform infrared analysis to the study of coal macerals: an example from the Late Jurassic to Early Cretaceous coals of the Mist Mountain Formation, British Columbia, Canada. International Journal of Coal Geology 32, 55-67. DOI 10.1016/S0166-5162(96)00030-4

Mastalerz, M. \& Bustin, R.M. 1997. Variation in the chemistry of macerals in coals of the Mist Mountain Formation, Elk Valley coalfield, British Columbia, Canada. International Journal of Coal Geology 33, 43-59. DOI 10.1016/S0166-5162(96)00003-1

Modliński, Z. \& SzYmański, B. 2001. The Silurian of the Nida, Holy Cross Mts. and Radom areas, Poland - a review. Geological Quarterly 45, 435-454.

Morga, R. 2019. About the microstructure of the graptolite periderm - examples from the Holy Cross Mountains (Poland). 
IOP Conference Series: Earth and Environmental Sciences 362, art. 012076. DOI 10.1088/1755-1315/362/1/012076

Morga, R. \& KamińsKa, M. 2018. The chemical composition of graptolite periderm in the gas shales from the Baltic Basin of Poland. International Journal of Coal Geology 199, 10-18. DOI 10.1016/j.coal.2018.09.016

Morga, R. \& Pawlyta, M. 2018. Microstructure of graptolite periderm in Silurian gas shales of Northern Poland. International Journal of Coal Geology 189, 1-7.

DOI 10.1016/j.coal.2018.02.012

Mroczkowska-Szerszeń, M., Ziemianin, K., Brzuszek, P., MATYASIK, I. \& JANKowsKi, L. 2015. The organic matter type in the shale rock samples assessed by FTIR-ATR analyses. Nafta-Gaz 71, 361-369.

Mustafa, K., Sephton, M., Watson, J., Spathopoulos, F. \& Krzywiec, P. 2015. Organic geochemical characteristics of black shales across the Ordovician-Silurian boundary in the Holy Cross Mountains, central Poland. Marine and Petroleum Geology 66, 1042-1055.

DOI 10.1016/j.marpetgeo.2015.08.018

Painter, P.C., Snyder, R.W., Starsinic, M., Coleman, M.M., Kuehn, D.W. \& Davis, A. 1981. Concerning the application of FT-IR to the study of coal: A critical assessment of band assignments and the application of spectral analysis programs. Applied Spectroscopy 35, 475-485.

DOI $10.1366 / 0003702814732256$

Petersen, H.I. \& Nytoft, H.P. 2006. Oil generation capacity of coals as a function of coal age and aliphatic structure. Organic Geochemistry 37, 558-583.

DOI 10.1016/j.orggeochem.2005.12.012

Petersen, H.I., Schovsbo, N.H. \& Nielsen A.T. 2013. Reflectance measurements of zooclasts and solid bitumen in Lower Paleozoic shales, southern Scandinavia: Correlation to vitrinite reflectance. International Journal of Coal Geology 114, 1-18. DOI 10.1016/j.coal.2013.03.013

Quirico, E., Rouzaud, J.-N., Bonal, L. \& Montagnac, G. 2005. Maturation grade of coals as revealed by Raman spectroscopy: Progress and problems. Spectrochimica Acta Part A 61, 2368-2377. DOI 10.1016/j.saa.2005.02.015

Schito, A., Corrado, S., Trolese, M., Aldega, L., Caricchi, C., Cirilli, S., Grigo, D., Guedes, A., Romano, C., Spina, A. \& Valentim, B. 2017. Assessment of thermal evolution of Paleozoic successions of the Holy Cross Mountains (Poland). Marine and Petroleum Geology 80, 112-132.

DOI 10.1016/j.marpetgeo.2016.11.016

Schovsbo, N.H., Nielsen, A.T., Klitten, K., Mathiesen, A. \& RASMUSSEN, P. 2011. Shale gas investigations in Denmark: Lower Palaeozoic shales on Bornholm. Geological Survey of Denmark and Greenland Bulletin 23, 9-14.
Smolarek, J., Marynowski, L., Spunda, K. \& Trela, W. 2014. Vitrinite equivalent reflectance of Silurian black shales from the Holy Cross Mountains, Poland. Mineralogia 45, 79-96. DOI 10.1515/mipo-2015-0006

Sobkowiak, M. \& Painter, P. 1992. Determination of the aliphatic and aromatic $\mathrm{CH}$ contents of coals by FT-i.r.: studies of coal extracts. Fuel 71, 1105-1125.

DOI 10.1016/0016-2361(92)90092-3

SuchÝ, V., Šafanda, J., SÝkorová, I., Stejskal, M., Machovič, V. \& Melka, K. 2004. Contact metamorphism of Silurian black shales by a basalt sill: geological evidence and thermal modelling in the Barrandian Basin. Bulletin of Geosciences 79, 133-147.

SuchÝ, V., SÝkorová, I., Stejskal, M., ŠAfanda, J., Machovič, V. \& NovotnÁ, M. 2002. Dispersed organic matter from Silurian shales of the Barrandian Basin, Czech Republic: optical properties, chemical composition and thermal maturity. International Journal of Coal Geology 53, 1-25. DOI 10.1016/S0166-5162(02)00137-4

TeichmÜLler M. 1978. Nachweis von Graptolithen - Periderm in geschieferten Gesteinen mit Hilfe kohlenpetrologischer Methoden. Neues Jahrbuch für Geologie und Paläontologie, Monatshefte 7, 430-447.

Toмczyкowa, E 1958. Fauna z łupków graptolitowych syluru niecki bardziańskiei Gór Świętokrzyskich. Geological Quarterly 2, 321-346.

Towe, K.M. \& UrbaneK, A. 1972. Collagen-like structure in Ordovician graptolite periderm. Nature 237, 443-445. DOI $10.1038 / 237443 \mathrm{a} 0$

Trela, W. \& Salwa, S. 2007. Lithostratigraphy of the Lower Silurian in Bardo Stawy (southern Holy Cross Mountains): relation to sea level change and oceanographic circulation. Przegląd Geologiczny 55, 971-978.

Tuinstra, F. \& Koenig, J.L. 1970. Raman spectrum of graphite. Journal Chemical Physics 53, 1126-1130.

DOI 10.1063/1.1674108

WANG, S.H. \& Griffiths, P.R. 1985. Resolution enhancement of diffuse reflectance IR spectra of coals by Fourier selfdeconvolution, 1, C-H stretching and bending modes. Fuel 64, 229-236. DOI 10.1016/0016-2361(85)90223-6

Wang, S., TANG, Y., Schobert, H., Jiang, D., Guo, X., Huang, F., Guo, Y. \& Su, Y. 2013. Chemical compositional and structural characteristics of Late Permian bark coals from Southern China. Fuel 126, 116-121. DOI 10.1016/j.fuel.2014.02.026

Więceaw, D., Kotarba, M., Kosakowski, P., Kowalski, A. \& Grotek, I. 2010. Habitat and hydrocarbon potential of the lower Paleozoic source rocks in the Polish part of the Baltic region. Geological Quarterly 54, 159-182. 